\title{
INTERNALISASI NILAI-NILAI KARAKTER PESERTA DIDIK DALAM PEMBELAJARAN TAHSIN DAN TAHFIDZ AL-QUR'AN DI MA TAHFIZHIL QUR'AN YAYASAN ISLAMIC CENTRE SUMATERA UTARA
}

\author{
Duma Mayasari* \\ *Mahasiswa S2 PAI FITK UIN Sumatera Utara
}

\begin{abstract}
Al-Qur'an as a guide to Muslim life that we must read and practice it. Tahsin and tahfidz learning methods are one of the ways taken by someone in the process of reading and memorizing the Qur'an correctly and correctly so that it is always remembered and can speak it fluently outside the head without seeing the text of the Qur'an. This study uses a qualitative approach. While the method of collecting data using observation or observation, interviews, field notes and study documents. The results of this study can be stated that through tahsin learning and tahfidz Al-Qur'an in the Islamic School of North Sumatra Islamic Madrasah Aliyah can form students who have good morals or morals from the learning process. In the learners will be embedded a sense of sincerity, discipline, honesty, patience, trustworthiness, religious, hard work, istiqomah and responsible that is applied in everyday life because it has permeated and inspired the meaning of the Qur'an.
\end{abstract}

Keywords: Internalization of Character Values of Students, Tahsin Learning and Tahfidz Al-Qur'an.

\section{PENDAHULUAN}

Pembinaan karakter bagi peserta didik di sekolah sangat penting, agar terbentuk jiwa-jiwa yang berakhlakul kharima sebagai bekal dalam kehidupan bermasyarakat karena peserta didik merupakan out put untuk merealisasikan masa depan bangsa sebagai generasi penerus dalam melanjutkan pembangunan nasional dan kemasyarakatan. Karena karakter dalam sudut pandang Islam, tidak ada disiplin ilmu yang terpisah dari etika Islam. Dan pentingnya komparasi antara akal dan wahyu dalam menentukan nilai-nilai moral terbuka untuk diperdebatkan. Dalam Islam terdapat tiga nilai utama, yaitu akhlak, adab, dan keteladanan.

Berbagai upaya yang bisa dilakukan sebagai penguatan nilai karakter. Salah satunya adalah dengan menanamkan kembali nilai-nilai karakter kepada siswa melalui proses pembelajaran diantaranya melalui pembelajaran tahsin dan tahfizd Al-Qur'an. Mengajari anak membaca, mempelajari dan menghafalkan AlQur'an merupakan perintah dalam ajaran Agama Islam. Karena untuk memahami ajaran Agama Islam haruslah dipelajari dan untuk mempelajarinya harus mampu membacanya. Karena tujuan utama dari pembelajaran tahfidz Al-Qur'an adalah pembentukan kepribadian pada diri siswa yang tercermin dalam tingkah laku dan pola pikirnya dalam kehidupan sehari-hari, maka pembelajaran tahfidz Al-Qur'an 
tidak hanya menjadi tanggung jawab guru tahfidz Al-Qur'an seorang diri, tetapi dibutuhkan dukungan dari seluruh komunitas disekolah, masyarakat, dan lebih penting lagi adalah orang tua. Sekolah harus mampu mengkoordinir serta mengkomunikasikan pola pembelajaran tahfidz Al-Qur'an terhadap beberapa pihak yang telah disebutkan sebagai sebuah rangkaian komunitas yang saling mendukung dan menjaga demi terbentuknya siswa berakhlak dan berbudi pekerti luhur. Karena hal yang terpenting dalam proses pembelajaran tahfidz Al-Qur'an adalah adanya perubahan prilaku yang baik dalam kehidupan sehari-harinya sebagai wujud dari aplikasi pengetahuan yang telah didapat. Maka tepat jika dikatakan bahwa penerapan pembelajaran tahfidz Al-Qur'an disekolah adalah sebagai pilar pendidikan karakter yang utama. Tahfidz Al-Qur'an mengajarkan pentingnya penanaman akhlak yang dimulai dari kesadaran beragama pada anak.

\section{KAJIAN TEORETIS}

Internalisasi pada hakikatnya berasal dari kata intern atau kata internal yang seringkali diartikan bagian dalam atau di dalam. Sedangkan secara lugas pengertian internalisasi adalah penghayatan. Internalisasi menjadi bagian penting dalam bentuk mobilitas sosial karena sebagai pembuktian bahwa masyarakat akan selalu bergerak mengikuti perubahan sosial yang ada. roses internalisasi berpangkal dari hasrat-hasrat biologis dan bakat-bakat naluri yang sudah ada dari warisan dalam organisme tiap individu yang dilahirkan. Akan tetapi, yang mempunyai peranan terpenting dalam hal membangun manusia kemasyarakatan itu adalah situasi-situasi sekitar, macam-macam individu lain di tiap-tiap tingkat dalam proses sosialisasi dan enkulturasinya.

Pengertian tentang internalisasi antara lain sebagai berikut: (1) Chaplin (2005) internalisasi adalah sebuah proses karena didalamnya ada unsur perubahan dan waktu dan internalisasi (internalization) diartikan sebagai penggabungan atau penyatuan sikap, standar tingkah laku, pendapat, dan seterusnya di dalam kepribadian, (2) Nurdin (2014) Internalisasi merupakan upaya menghayati dan mendalami nilai agar nilai tersebut tertanam dalam diri setiap manusia, (3) Mulyana, (2004) menjelaskan internalisasi diartikan sebagai menyatunya nilai dalam diri seseorang, atau dalam bahasa psikologi merupakan penyesuaian keyakinan, nilai, sikap, praktik dan aturan-aturan baku pada diri seseorang. Pengertian ini mengisyaratkan bahwa pemahaman nilai yang diperoleh harus dapat dipraktikkan dan berimpliksi pada sikap. Internalisasi ini akan bersifat permanen dalam diri seseorang.

Nilai dalam bahasa Inggris value, berasal dari bahasa latin valere atau bahasa Prancis kuno valoir. Sebatas arti denotatifnya, valere, valoir, value atau nilai dapat dimaknai sebagai harga. Secara umum telah kita ketahui bahwa nilai adalah sesuatu yang berharga dan berguna bagi kehidupan manusia. Allfort sebagaimana dikutip oleh Mulyana (2004) "nilai adalah keyakinan yang membuat seseorang bertindak atas dasar pilihannya. Gunawan (2012) menyebutkan bahwa, 
nilai yang benar dan diterima secara universal adalah nilai yang menghasilkan suatu perilaku dan perilaku itu berdampak positif, baik bagi yang menjalankan maupun bagi orang lain.

Nilai mempunyai peranan yang sangat penting dalam kehidupan manusia, sebab nilai dapat menjadi pegangan hidup, pedoman, penyelesaian konflik, memotivasi, dan mengarahkan pandangan hidup. Nilai adalah suatu tipe kepercayaan yang berada dalam ruang lingkup sistem kepercayaan, dimana seseorang harus bertindak atau menghindari suatu tindakan mengenai sesuatu yang pantas atau tidak pantas untuk dikerjakan (Toha, 2006). Dengan demikian nilai dapat diartikan sebagai suatu tipe kepercayaan dan pijakan dalam suatu tindakan yang sudah melekat dalam diri manusia yang menjadi dasar bagi seseorang maupun kelompok.

Karakter berasal dari bahasa latin "kharakter", "kharassein", "kharak", dalam bahasa Inggris charakter dan dan dalam bahasa Indonesia "karakter", dan dalam Bahasa Yunani charakter, dari charassein yang berarti membuat tajam. (Majid dan Andayani, 2012). Menurut Kamus Umum Besar Bahasa Indonesia (2006) karakter didefinisikan sebagai tabiat; sifat-sifat kejiwaan, akhlak atau budi pekerti yang membedakan seseorang dengan yang lain, watak. Sedang kata berkarakter diterjemahkan sebagai mempunyai tabiat, mempunyai kepribadian, berwatak. Suyanto dan Muslich (2011) menyatakan bahwa karakter yaitu cara berpikir dan berperilaku seseorang yang menjadi ciri khas dari setiap individu untuk hidup dan bekerjasama, baik dalam keluarga, masyarakat dan negara.

Selanjutnya mengenai pengertian peserta didik dijelaskan Ratna (2014) adalah insan yang sedang berada dalam proses pertumbuhan, proses pencarian, selalu ingin mengetahui, makhluk bertanya. Mereka jelas berasal dari latar belakang sosial yang berbeda-beda dengan bakat dan kemampuan yang juga berbeda-beda. Menurut Ahmadi (2009) peserta didik adalah sosok manusia sebagai individu/pribadi (manusia seutuhnya). Individu di artikan sebagai seseorang yang tidak tergantung pada orang lain, dalam arti benar-benar seorang pribadi yang menentukan diri sendiri dan tidak dipaksa dari luar, mempunyai sifat-sifat dan keinginan sendiri.

Sementara itu, bila merujuk kepada Undang-Undang Republik Indonesia Nomor 20 Tahun 2003 tentang Sistem Pendidikan Nasional yang terdapat dalam Bab I Pasal 1 poin keempat, dijelaskan bahwa peserta didik itu adalah anggota masyarakat yang yang berusaha mengembangkan potensi diri melalui proses pembelajaran yang tersedia pada jalur, jenjang, dan jenis pendidikan tertentu. Sutrina (2013) menjelaskan peserta didik adalah individu yang berada dalam proses perkembangan dan pertumbuhan. Implikasi penyelenggaraan pendidikan dituntut untuk disesuaikan dengan keberadaan peserta didik untuk bisa dapat mengembangkan potensi yang dimilikinya karena potensi akan berkembang ketika layanan pendidikan tepat sesuai dengan tahap perkembangan dan pertumbuhan peserta didik. 
Tujuan internalisasi nilai-nilai karakter, karena internalisasi nilai-nilai karakter terkait erat dengan pendidikan nilai-nilai agama, bahkan pendidikan agama pada hakikatnya merupakan pendidikan nilai (Jalaluddin, 2001). Barnawi dan Arifin (2012) mendefinisikan pendidikan karakter sebagai proses belajar yang memungkinkan siswa dan orang dewasa untuk memahami, peduli, dan bertindak pada nilai-nilai etika inti, seperti; rasa hormat, keadilan, kebajikan, warga Negara yang baik, dan bertanggung jawab pada diri sendiri dan orang lain. Selain itu, pendidikan karakter dikatakan sebagai suatu sistem penanaman nilai-nilai karakter pada peserta didik yang meliputi komponen: kesadaran, pemahaman, kepedulian, dan komitmen yang tinggi untuk melaksanakan nilai-nilai tersebut, baik terhadap Allah SWT, diri sendiri, sesama, lingkungan, maupun masyarakat dan bangsa secara keseluruhan, sehingga menjadi manusia sempurna sesuai kodratnya (Mulyasa, 2012). Senada dengan pendapat tersebut Samani (2012) menjelaskan bahwa berbagai karakter yang harus dimiliki oleh kaum muslimin baik menurut hadist antara lain tentang menjaga harga diri.

\section{METODOLOGI PENELITIAN}

Penelitian ini dilaksanakan di Madrasah Aliyah Tahfizhil Qur'an Yayasan Islamic Centre Sumatera Utara. Pendekatan penelitian ini menggunakan metode kualitatif. Sumber data dalam penelitian ini adalah: (1) data primer diperoleh dari hasil wawancara dengan informan yaitu, kepala madrasah, guru-guru Al-Qur'an yang mengajar di MA Islamic Centre, pembantu kepala sekolah dibidang kurikulum, siswa-siswi, sarana prasarana dan data dokumentasi sekolah yang berkaitan dengan fukus penelitian, (2) suumber data sekunder diperoleh dari buku, arsip, serta dokumentasi. Sumber data sekunder merupakan sumber data pelengkap yang berfungsi melengkapi data yang diperlukan oleh data primer, seperti literatur, artikel dan berbagai buku yang bersifat teoritis, catatan peneliti dan berbagai data pendukung lainnya. Teknik pengumpulan data teknik observasi, teknik wawancara, catatan lapangan dan dokumen-dokumen. Prosedur pelaksanaan penelitian dilakukan dengan cara mereduksi data, menyajikan data dan membuat kesimpulan. Teknik penjaminan keabsahan data dilakukan dengan kredibilitas, ransferabilitas, dependablitas dan konfirmabilitas.

\section{HASIL PENELITIAN DAN PEMBAHASAN}

Pembelajaran tahfidz dilaksanakan dua jam pertama setiap harinya yang dibina oleh guru khusus tahfidz Al-Qur'an sedangkan khusus pembelajaran tahsin dipelajari tiga bulan pertama setelah sekolah dimulai. Pembelajaran tahsin dan tahfidz Al-Qur'an ini sudah dilaksanakan sejak berdirinya Yayasan Islamic Centre ini dan program tahfidz Al-Qur'an menjadi program unggulan di bandingkan sekolah-sekolah lainnya. Dasar pembelajaran tahsin itu sendiri adalah standarnisasi bacaan agar bisa menghafal Al-Qur'an. Sedangkan tahfidz Al- 
Qur'an ini yaitu pola pendidikan Islam yang sebenarnya itu diawali dengan pendidikan Al-Qur'an.

Proses pembelajaran tahsin dan tahfidz Al-Qur'an yang dilakukan adalah: "untuk belajar tahsin guru akan mendiagnosa penyakit masing-masing peserta didik, seperti tajwid dan makhroj hurufnya. Sedangkan untuk tahfidznya guru akan menyuruh salah satu peserta didik untuk membaca ayat dan dilanjutkan oleh semua kawannya (dibaca bersama-sama). Internalisasi atau proses pelaksanaan penerapan nilai-nilai karakter peserta didik bertujuan untuk membuktikan kebenaran teori dengan data lapangan. Proses pelaksanan pembelajaran internalisasi nilai-nilai karakter peserta didik melalui kegiatan pembelajaran tahsin dan tahfidz Al-Qur'an.

Tujuan untuk mempelajari tahsin dan tahfidz Al-Qur'an adalah untuk bisa menumbuhkan rasa kecintaan peserta didik terhadap Al-Qur'an, karena dikatakana dalam sebuah hadits bahwa sebaik-baik manusia adalah yang belajar Al-Qur'an dan mengamalkannya. Selain itu, diharapkan dengan adanya program ini peserta didik juga memperbaiki kualitas bacaannya dan dapat menjadi penghafal Al-Qur'an dan menambah wawasan pengetahuan bagi peserta didik di Madrasah Aliyah Islamic Centre Sumatera Utara. Dengan mendekatkan diri kepada Al-Qur'an otomatis perilaku peserta didik pun akan berubah seiring berjalannya waktu karena peserta didik setiap hari berhadapan dengan Al-Qur'an dan peserta didik akan terus berusaha, mengasah pikiran dan mencari hakikat dari Al-Qur'an itu sendiri.

Peranan nilai-nilai karakter yang diterapkan di Madrasah Aliyah tersebut adalah berfokus pada nilai disiplin dan kerja keras. Disiplin merupakan kepatuhan atau tunduk kepada pengawasan /pengendalian yang bertujuan sebagai upaya mengendalikan diri dan sikap mental individu dalam mengembangkan kepatuhan dan ketaatan terhadap peraturan dan tata tertib yang berlaku di madrasah ini, berdasarkan atas dorongan dan kesadaran yang muncul dari dalam hati. Di dalam lingkungan madrasah sendiri disiplin itu harga mati yang benar-benar harus diterapkan dan tidak bisa ditawar-tawar karena kedisiplinan itu akan mendorong seseorang menuju kesuksesan seperti halnya dalam menghafal Al-Qur'an. Sedangkan kerja keras merupakan usaha/berusaha sekuat tenaga untuk mendapatkan hasil yang maksimal. Maka dari itu peserta didik yang menginginkan suatu kesuksesan hendaklah dimulai dengan kedisiplinan dan kerja keras yang tinggi, sebab kedua hal inilah yang akan menuntun peserta didik untuk mendapatkan suatu yang diinginkan dan kedua sifat ini tidak dapat dipisahkan dan harus dijadikan sebagai prinsip dalam kehidupan sehari-hari.

Etika dalam menghafal Al-Qur'an yang diterapkan di Madrasah Aliyah Islamic Centre Sumatera Utara adalah: (1) niat yang ikhlas untuk menghafal AlQur'an, (2) siap meluangkan waktu untuk menghafal dan mengulang hafalan, (3) mentaati semua peraturan yang berlaku di Islamic Centre Sumatera Utara, (4) menjauhkan diri dari akhlak tercela, bermuka riang, menyebarkan salam, suka 
membantu teman dalam kebaikan dan ketaqwaan, (5) patuh dan hormat kepada guru, (6) selalu dalam keadaan berwudhu setiap hari, bersih secara fisik dan penampilan, (7) selalu berdoa agar Allah SWT memberikan kemudahan dalam menghafal, dan (8) patuh dan hormat kepada orang tua dan selalu mendoakan mereka.

Metode untuk menghafalkan Al-Qur'an sudah di tentukan oleh pihak Madrasah atau yayasan seperti metode muraja'ah, talaqqi dan sima'i. Terdapat langkah-langkah dalam menghafal yang dibagi dalam beberapa bagian seperti: (1) berdoa sebelum menghafal, (2) baca semua yang akan dihafal $2 \mathrm{X}$ diperdengarkan kepada teman yang telah hafal, (3) baca satu ayat sampai lancar tanpa ada kesalahan mad dan barisnya, (4) ayat yang akan dihafal dipotong menjadi beberapa bagian sesuai waqaf/ibtida kemudian dibaca dengan melihat 1520 kali, (5) kemudian ayat yang dipotong dibaca dan diulang 15-20 kali tanpa melihat mushaf, (6) menyatukan potongan ayat-ayat yang telah dihafal dan mengulang 5-10 kali, (7) ayat yang telah dihafal dirangkai dengan ayat berikutnya sebanyak 5 kali, dan (8) semakin banyak ayat yang dihafal semakin sering ulangan tangkaian ayat dilakukan

Sedangkan metode mengulang hafalan ada beberapa cara yang diterapkan, dijelaskan sebagai berikut: (1) berdoa sebelum mengulang hafalan, (2) mengulang hafalan 3 sampai 5 juz setiap hari, (3) mengulang dengan melihat mushaf serta membayangkan di mana posisi ayat, (4) mengulang dengan membuka mushaf tapi tidak boleh melihat mushaf (hanya dilihat untuk memperbaiki posisi ayat apabila tidak terbayang dalam pikiran, (5) mengulang dengan menutup mushaf, dan mushaf boleh dilihat kalau hafalan sama sekali tidak terbayang, (6) muraja'ah dengan teman, (7) hafalan dibawa dalam sholat, dan (8) melakukan simaan AlQur'an dengan teman.

Selanjutnya utuk metode melancarkan hafalan ada banyak cara yang diterapkan, diantaranya adalah: (1) mengulang hafalan harus benar-benar berkonsentrasi (menyatukan hati dan fikiran, (2) dalam mengulang (jumlah juz) harus sama setiap hari dan menyetor kepada guru, (4) dalam menghafal tidak boleh terus menerus melihat mushaf, (4) beri tanda ayat/kalimat yang salah agar mudah memperbaiki, (5) ayat yang dibaca tidak lancar, diulang sebanyak 5-10 kali seperti halnya menghafal, dan (6) tasmi' kepada guru agar terhindar dari kesalahan mad dan baris

Manfaat mempelajari Al-Qur'an maupun menghafalnya adalah mengasah hati dan mengasah pikiran. Manfaat lainnya bagi seluruh peserta didik, diantaranya, pertama, mendapat keberkahan dari Allah SWT, kedua, memang ciri khas dari yayasan islamic centre ini sendiri yang membedakan dari sekolahsekolah lain. Ketiga, peserta didik menjadi tahu cara membaca Al-Qur'an dengan baik, mengerti dengan mahrajnya dan panjang pendeknya, peserta didik juga mampu membaca dengan bagus". 
"Manfaat lainnya adalah adap kepada guru, karena guru merupakan orang tua kedua mereka di sekolah. Sebagai pengganti orang tua di sekolah, guru sangat banyak berjasa dalam mendidik, membina dan memberikan ilmu pengetahuan sehingga diberi gelar guru tanpa jasa. Adap yang ditunjukan dan ditanamkan peserta didik di madrasah adalah: (1) tidak mencari kekurangan, kelemahan dan kesalahan guru, (2) tidak menjelekkannya dan membicarakannya, melainkan kita harus membantu, membelanya ketika dijelekkan orang lain, (3) selalu mendoakan atas segala kebaikanya, karena sudah memeberikan ilmu kepada kita, yang sudah ia ajarkan, (4) mengambil teladan atas kebaikan guru dan mengamalkan akhlak mulia yang dilakukannya, (5) tidak memotong perkataan beliau, serta menjaga adab berbicara dan diskusi dengannya, (6) kita harus taat kepada guru dalam semua perkara, kecuali ada beberapa perkara maksiat kepada Allah SWT, (7) berbicara dengan beliau dengan lemah lembut dan penuh dengan rendah diri kepada guru, (8) meminta izin kepada guru ketika tidak hadir sekolah dan akan keluar kelas karena ada keperluan, (9) saat datang ke sekolah langsung salam kepada guru apabila berjumpa, (10) memberi perhatian besar dalam pengajaran guru, duduk dengan sopan, dan dalam keadaan tenang, dan (11) rendah hati dihadapan guru. Dengan rendah hati maka ilmu yang masuk dalam dirimu akan lebih mudah.

Target dari hafalan dari pembelajaran tahfidz ini adalah peserta didik harus menyelesaikan 15 juz selama belajar di Madrasah Aliyah Islamic Centre ini, untuk anak kelas IX tiga bulan pertama di semester satu peserta didik akan belajar tahsin dan bulan berikutnya target hafalan adalah satu juz sedangkan disemester dua peserta didik harus hafal empat juz secara mutqin. Sementara untuk anak kelas XI target hafalan semester satu adalah 2,5 juz mutqin dan target hafalan semester dua adalah 2,5 juz mutqin. Dan untuk anak kelas XII target hafalan semester satu adalah 2,5 juz mutqin dan target hafalan semester dua adalah 2,5 juz mutqin".

Hafalan peserta didik akan diuji setiap semester dengan uraian teknis, sebagai berikut: (1) durasi hari ujian adalah 6 hari (Satu minggu/12 kali pertemuan), (2) durasi jam ujian adalah 2 jam 15 menit, (3) penguji dan peserta ujian diperbolehkan ujian di luar jam yang telah ditetapkan, akan tetapi durasi ujian harus tetap 6 hari dan 2 jam 15 menit setiap hari, (4) penguji adalah guru yang masuk sesuai jadwal yang telah ditetapkan, (5) perbaikan nilai ujian hanya diperbolehkan dalam durasi hari dan waktu yang telah ditetapkan (6 hari dan 2 jam 15 menit).

\section{SIMPULAN}

Proses pembelajaran Al-Qur'an adalah sebuah proses perubahan tingkah laku peserta didik karena guru akan mendidik, mengajar, membimbing, dan melatih peserta didik untuk membaca dan menghafal Al-Qur'an dengan fasih dan benar sesuai dengan kaidah Ilmu tajwid agar peserta didik terbiasa belajar membaca Al-Qur'an dalam kehidupan sehari-hari. Dengan demikinan, melalui 
pembelajaran tahsin dan tahfidz Al-Qur'an di Madrasah Aliyah Islamic Centre Sumatera Utara ini dapat membentuk peserta didik yang memiliki akhlak atau moral yang baik dari proses pembelajaran tersebut, dalam diri peserta didik akan tertanam rasa keikhlasan, disiplin, kejujuran, kesabaran, amanah, religius, kerja keras, istiqomah dan bertanggung jawab yang diaplikasikan dalam kehidupan sehari-hari baik dalam lingkungan sekolah dan masyarakat karena telah meresapi dan menjiwai makna dari Al-Qur'an tersebut.

Evaluasi pendidikan karakter dalam pembelajaran tahfidz Al-Qur'an di Madrasah Aliyah Tahfizhil Qur'an Yayasan Islamic Centre Sumatera Utara ini berjalan dengan baik, evaluasi ini dilakukan baik oleh guru tahsin dan tahfidz, wali kelas atau guru yang di tunjuk oleh sekolah untuk membantu proses penilaian. Penilaian dilakukan ada yang sifatnya dilakukan harian, bulanan atau semesteran sesuai dengan target yang akan di capai. Namun hasil evaluasi penanaman pendidikan karakter belum bisa di presentasikan karena dalam penilaiannya di gabungkan dengan nilai pengembangan diri dan pembiasaan yang dilakukan si sekolah. Untuk pembelajaran tahsin dan tahfidz Al-Qur'an di Madrasah Aliyah Tahfizhil Qur'an Yayasan Islamic Centre ini penekanannya adalah jumlah hafalan bukan pada karakternya. Penerapan karakter hanya sebagai penunjang untuk suksesnya target hafalan peserta didik.

Keberhasilan yang dicapai dari proses pembelajaran tahsin dan tahfidz AlQur'an di Madrasah Aliyah Islamic Centre Sumatera Utara adalah keberhasilan dari proses pembelajaran tersebut adalah $75 \%$ berhasil dengan target hafalan yang sudah ditetapkan, dan kalau untuk keberhasilan tahsin tidak didata disebabkan karena masalah setiap peserta didik berbeda-beda. Untuk peserta didik yang mencapai target hafalan akan diberi reward, yaitu dengan mempromosikan peserta didik ke ajang MTQ tingkat kecamatan, kota dan tingkat provinsi yang di beritakan melalui mading.

\section{REKOMENDASI}

Rekomendasi yang dapat dikemukakan diantaranya adalah: (1) kepada Kepala Madrasah hendaknya meningkatkan pengawasan dan perhatian terhadap kegiatan proses pembelajaran tahsin dan tahfidz Al-Qur'an, agar program tahsin dan tahfidz ini dapat meningkatkan kualitas program tersebut. Meningkatkan kerja sama dengan guru dan wali murid yang bertujuan untuk penerapan nilai-nilai karakter peserta didik melalui pembelajaran tahsin dan tahfidz di Madrasah Aliyah Yayasan Islamic Centre Sumatera Utara, (2) kepada Guru-guru tahfidz sebaiknya lebih bersinergi dan meningkatkan kinerja sebagai seorang guru. Melaksanakan tugas pendidikan dengan bertanggung jawab dan profesionalisme. Selanjutnya dapat memberikan inovasi pembelajaran sehingga dapat mendorong motivasi peserta didik dalam belajar dan menghafal Al-Qur'an agar target hafalan yang telah ditentukan tercapai, dan (3) kepada Peserta didik Madrasah Aliyah Islamic Centre Sumatera Utara, lebih giat lagi dalam belajar dan meningkatkan 
semangat dalam mengahafalkan Al-Qur'an, menunjukkan karakter yang lebih baik lagi karena telah menjiwai isi Al-Qur'an dan taat terhadap peraturan yang berlaku dilingkungan Madrasah Aliyah Islamic Centre Sumatera Utara.

\section{DAFTAR PUSTAKA}

Chaplin, J.P, (2005) Kamus Lengkap Psikologi, Jakarta: Raja Grafindo Persada,

Daryanto dan Darmiatun, Suryatri, (2013) Implementasi Pendidikan Karakter di Sekolah Yogyakarta: Penerbit Gava Media.

Hamid, Hamdani dan Beni Ahmad Saebani, ( 2015) Pendidikan Karakter Perspektif Islam, (Bandung: Pustaka Setia.

Majid, Abdul dan Andayani Dian, (2012) Pendidikan Karakter Perspektif Islam Bandung: Remaja Rosdakarya

Makmur, Jamal, (2011) Pendidikan Karakter di Sekolah, Yogyakarta: Diva Press.

Moeleong, Lexy J, (2014) Metode Penelitian Kualitatif, Bandung: Remaja Rosdakarya.

Mulyana, Rahmat, (2004) Mengartikulasikan Pendidikan Nilai, cet ke-1 Bandung: Alfabeta.

Mulyasa, E. (2012) Menjadi Guru Profesional Menciptakan Pembelajaran Kreatif dan Menyenangkan, Bandung: Rosda Karya.

Muslich, Masnur, (2011) Pendidikan Karakter: Menjawab Tantangan Krisis Multidimensial, Jakarta: Bumi Aksara.

Mustari, Muhammad, dkk, (2014) Nilai Karakter (Refleksi untuk Pendidikan) cet ke-1, Jakarta: Rajagrafindo Persada.

Ratna, Nyoman Kutha, (2008) Peranan Karya Sastra, seni, dan Budaya dalam Pendidikan Karakter, Yogyakarta : Pustaka Pelajar, 2014 Permenag No 2 tahun 2008.

Rusydi Ananda dan Amiruddin. (2017) Inovasi Pendidikan. Melejitkan Potensi Teknologi dan Inovasi Pendidikan. Medan: Widya Puspita.

Satori, Djam'an dan Komariah, Aan, (2011) Metodologi Penelitian Kualitatif, Bandung: Alfabeta.

Sutrina, (2013) Perkembangan dan Pertumbuhan Peserta Didik, Yogyakarta: Andi Ofset.

Suyanto, (2010) Pendidikan Karakter Teori dan Aplikasi, Jakarta: Rineka Cipta.

Syabrani, Amirullah, (2012) Pendidikan Karakter, Jakarata: Prima Pustaka.

UU RI No. 20 Tahun 2003 Tentang System Pendidikan Nasional, Jakarta: sinar grafika. 